616. 153. 1 : $577.158 .7: 615.31-002.4$

\title{
無カタラーゼ血液症に出現する \\ 口腔壊痓についての実験的研究
}

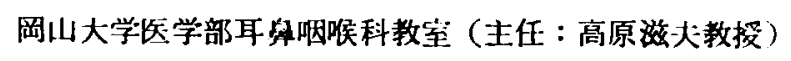

土 井 勝三 郎

〔昭和33年12月17日受稿〕

第 1 章 緒 言

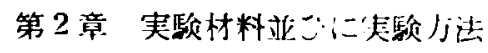

第 1 節 実颃材料

第 2 節 実駼方运

\section{第1章 緒言}

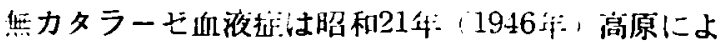

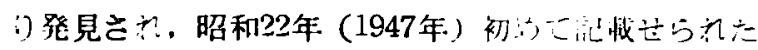

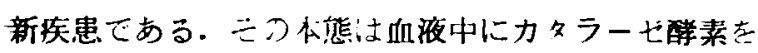

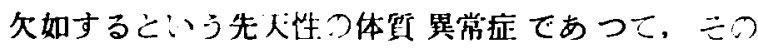
娞，高原，吉屋，三原等つ研究により検查叮能の組繳

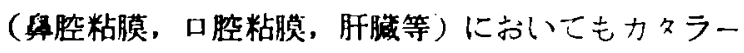
セ醇菜欠如しこいるここが判明した。

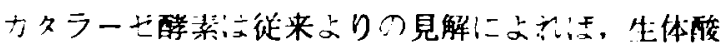
化によ）発生した過酸化水素索特殊的に分解してこ学 を無毒化するとい门う，従つて生体ににつて们久の

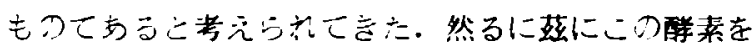
欠如方尚人間が生佸し，しかも元机らの䄪半数におい て纤年期に特有公山腔聅患を有することが方るか，元 の他の点では正常人さ何等変るこしなく健康に生活し

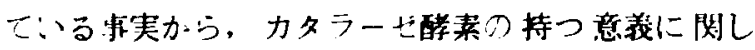
て、苍いてい人間のメタポリスムの解积に是義在抱か。 さるをえかくなつた。

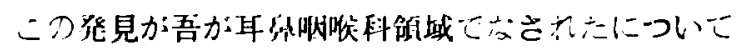

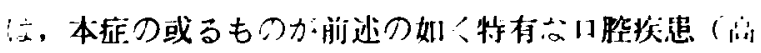
原氏病）を現わすここによ并・本在の発見絓過につい ては高原，宮本か：詳䋱に報告しているのて、本交では これを省略し，発見の端楮とふつた口腔疾患の大略に つ、て述べこことする．先ず山腔将患はこの大半が

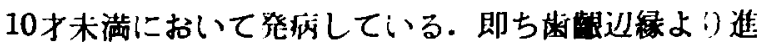

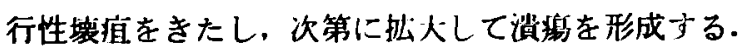

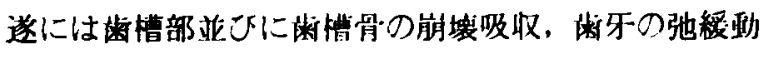

次

\begin{tabular}{|c|c|}
\hline 第3章 & 実臨成績 \\
\hline 第 4 童 & 考按湴じに総颃 \\
\hline 第 5 章 & 結語 \\
\hline
\end{tabular}

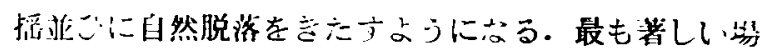

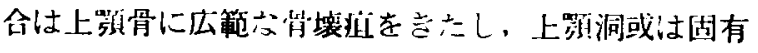
自腔と交通するものがある・また軟部組織例えば煩粘 脱，舌辺緑，舌根部に壞瘨が進展することもあ门，三

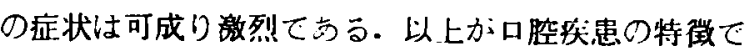
あるが，高原の発見を機しして今日まてに追加報告せ

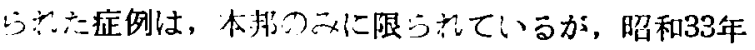
11月30日現在17家禾38例に及んでいる。この38例什,

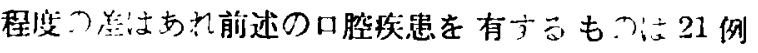
(55\%) であつた.

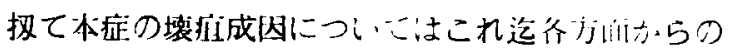

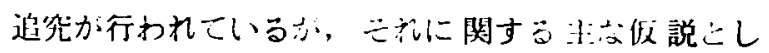

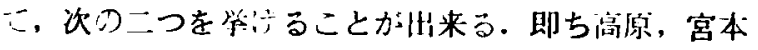

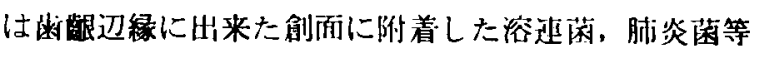
のカタラーゼを産生しない過酸化水菜应尘菌によつこ

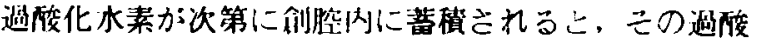
化水䒺にカィラーゼ夲久如する血液が接触し，組織に

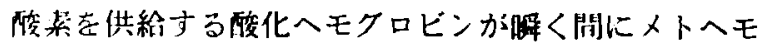

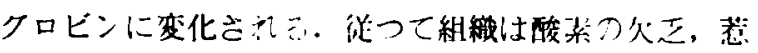

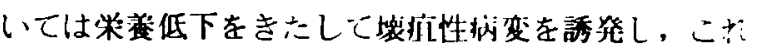
は更に練菌感染を容易にするたか，循罡的に病变は拉 人广るつこあううと述へてい、方。次に上代，吉屋，向

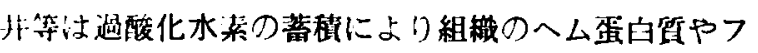
ラビンヌクレオチツドの如き呼吸酵菜が破呅されて䘫 扰が起こるのであううと述へている．私は本症に出現

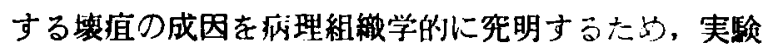

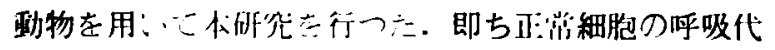


謝系の中で邀酸化水素の產生から゙の暨度に行われ，ま だのうちどの暨度がカタラーゼにより利用乃丞処理 せられているかは，現在の処なお不明てあるか，過酸

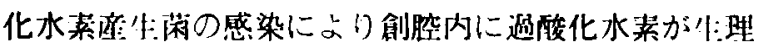

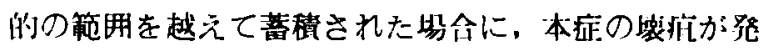

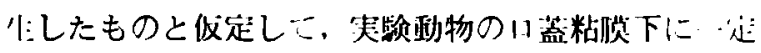

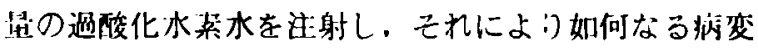

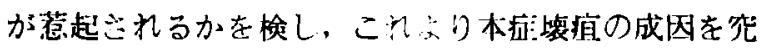
明せんとしたのごある。

\section{第 2 章 実験材料並びに実験方法}

\section{第 1 管 実验村料}

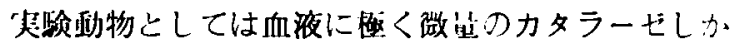
会有せず，本粫患者の血液と最も近い状態にある家

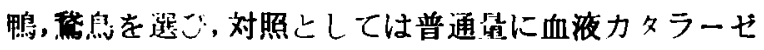

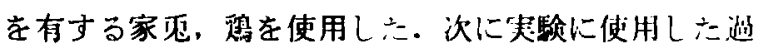
酸化水素水は，市眅のオキシドールをケめWarburg

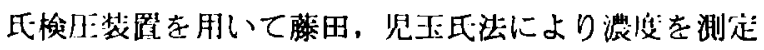
しここれに蔒溜水を加えて1\%とし使用した。

\section{第 2 節 実唤方法}

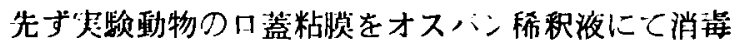
した後， $1 \%$ 過酸化水素水 $0.5 \mathrm{cc}$ を粘膜下に反復注射 した。一定時問後肉眼的所見を镜察し，或るものにお いては宗真摄影をも行つた。その後断頭し、組織は注 射中心部と周辺部亡に分けてこれを奶除し，10\%フオ ルマリン液による固定を行つ方。家鴨，瑟鳥，琶にお いては Celloidin 包埋を行い15 の切片標本とし，

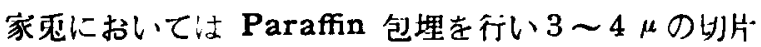
標本として各々 Haematoxylin-Eosin 重染也を施し 検鏡した。

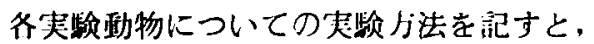

A 家鴨に扔ける実䮖

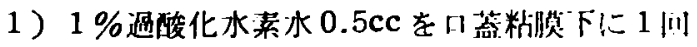
过射し，24時閣後に断顽固定。

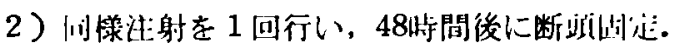

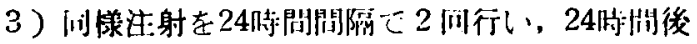
二断䫓国定.

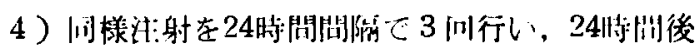
に断毫(胡这.

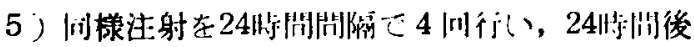
に断语倜定.

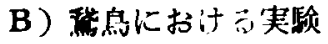

$1 \%$ 過酸化水素水 $0.5 \mathrm{cc}$ を有侧门算粘顺下に 1 [回，

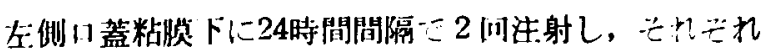

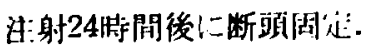

C）家乘における実跧

1） $1 \%$ 過酸化水素水 $0.5 \mathrm{cc}$ を口蓋粘膜下に 1 [川! 生射し，24时間後に断喕固定.

2) 间様法射を24時閣間隔で 2 问行い，24時問俊 に断新怵这。

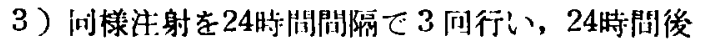
に断站湖拄。

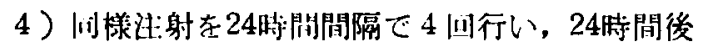

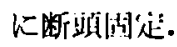

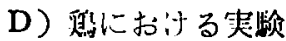

$1 \%$ 過陵化水菜水 $0.5 \mathrm{cc}$ を口蓋粘膜下に 1 回注射 ᄂ, 24時閂後に断䌿固定.

\section{第3 章実験成績}

\section{A）家鸭における実験成績}

1） $1 \%$ 過酸化水素水 $0.5 \mathrm{cc} 1$ 问注射 24 時問後の 岁会.

肉眼的所見：法射部位に炏向色の苔被を生じ，二カ 周畍はやや㥕亦す。苔被は粘脱面よりやや隆起してい る.

\section{影微鏡所見 .}

a) 这射小心部

粘膜上皮には变化がしく，上皮下亚びに腺間犋に 非常に强い㑑血を認め, 線維素の析出がある。結締織 は㽝粗となり浮腫状を呈し、多数の多形核細胞、単核 細胞の浸润が認められる。腺には変化を認めない．筋 稩胞は空胞变性或は硝子㥞变性を起している。血管壁 には大した变化は認められないが，ただ太い卹管の外 膜の結蟐䄉が硝子㥞变性を起している.

b ）过射周辺部

粘脱上皮及び上皮下には变化なく，腺と筋缕との間.

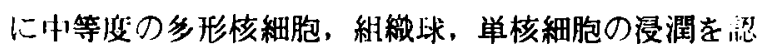
める.ま亡所々に軽度の怗血孝認める。

2) 1 问计射48時間後の傷合.

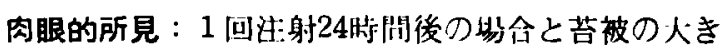

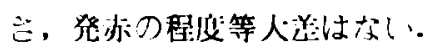

影徽鏡所見 :

a) 注射小心部

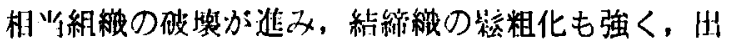
血も強佼てあ し, 㳭部絬締織には多形核細胞, 学核細胞, 組絊球方

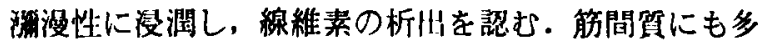
数の紐胞浚澗か及ひ、管線維にはか芯り著しい变性が

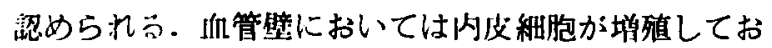
り，また外膜へ行くほど強い情の膨化と外膜の硝子拣 
变性並びに線維素の析出が認められる。また外膜より 内膜に至るまで著明な白血球の骎潤が認められる。或 る血管においては管腔に白血球及び亦血球が䒕满して おり，更に進むと新鮮な血栓を形成し，腔の閉塞之れ たものがある. 以上の変化は一般に静脈より動脈にお いて強く認められる。腺練胞の変化は認められ心い。

b ）注射周辺部

結締織の粗化並しに細胞浸潤は中心部と大体问程 度である．また出血並こに強い整血も認められる。腺 細胞は非常に透明と心引，粘庥分泌のたかまつている 像が見られる。

3) 24時間間隔 2 回过射24時間後刀場合.

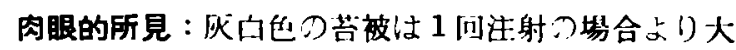
きくなり、また色もやや黄味をおしてくう。苔被周困 ○発赤もやや強くなる。

\section{㩆微鏡所見 :}

a) 注射中心箖

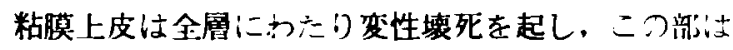

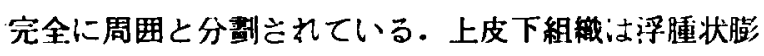
化, 稩胞浸淍. H血が高度である. 深部結締樴の臌化 も強い，血管には整血が認められ，顆粒細胞が血管壁 並ひにその周囲に游计している。血管壁は一一般に膨化 しておう(特に動脈において著明)、太心動脈こは外

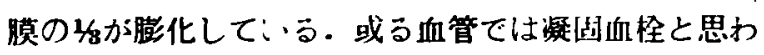
れるものが認めらてる.膨化した結締織の間にある筋 内束は強度の硝下様变性を起している。粘液腺, 烸液 腺及じこの周囲の結締織線維は膨化乃至肥厚してい 亏.

b ) 注射周边部

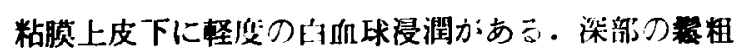

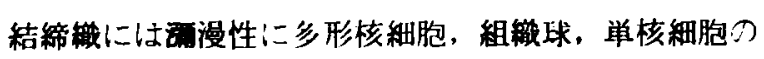

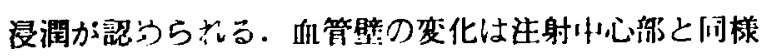
こある。

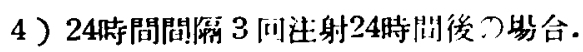

肉眼的所見：灰门出やや资味をおじ苔被は更に大

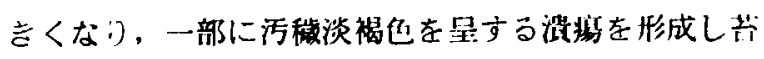

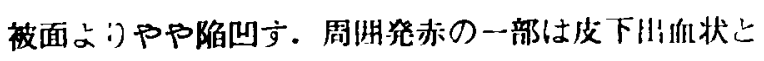
ふつている。

\section{彩碳鏡所見 :}

a) 注射中心稀

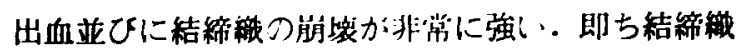
は膨化し浮腫状を呈している.筋層には物所により硝 子様变性が強く, 箭束内にも策核細胞, 少数の多形核 科胞つ浸潤が証められる。また筋線維には著しい萎維

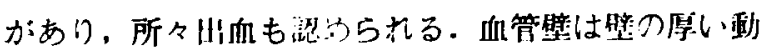

脈を除いては全体が硝子化している．大きな血管にお いて:は，その外側1ふ殆ど細胞の核がなく芯り，線維 腈造のみが残つている。中的は絊胞核は認められる が，組蟣が非常に膨化しており，稩胞には空胞変性が 强い，この状態は内に進むほど程度が弱まつているが 内膜にまで及んでいる．即ち内皮稩胞は少し增殖して いる部もあれば,ま心全然变化の認められない部もあ る.細い血管内には仙栓を認める。粘液腺及じ哑液腺 の腺練胞は背が低く吢り，分泌か抑制されている状態 を呈しているものもあれば，中にはほぼ正常の状態を 呈しているものも方る・リンパ管は強く肥大し少し 滞しているのか認内られる。

b ) 进射䧓辺部

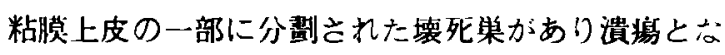
つているる。の底新には多数の多形核細胞の浸潤を認

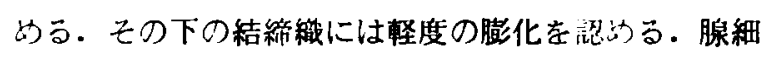
胞は背が低くなり，機能低下の像を示している.腺組 織の下の層には強い、組織の浮腫があり軽度の細胞浸潤 を伴つている．血管壁及び筋層の变化は注射中心部に 比較し幾分軽废で尚云。

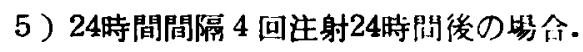

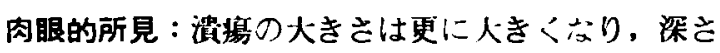
もやや梁くなる．色は緑出を括ひてくる．灰白色の苔 被も污程色となり大きさも大きさなる。

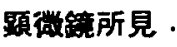

a) 注射中心竌

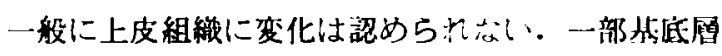

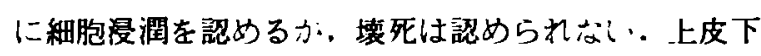
組織には練胞浸㵎の諰められる部がある。ひにい変化

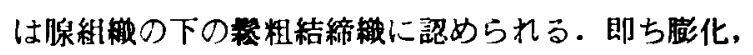
リンパ管の払張及じ出血が認められる。筋層には非尝

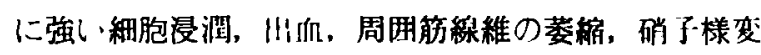

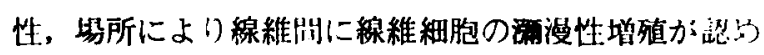

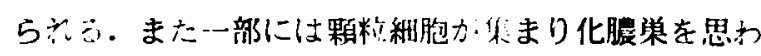

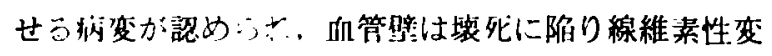
性参起している。

b) 过射周辺新

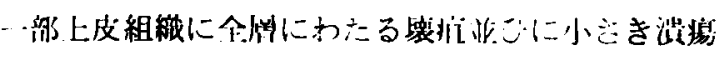

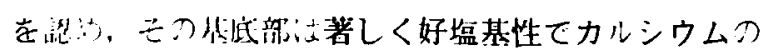
沈着を思わせる。またに皮組織の表面は一般にエオシ ンに好染し，上皮組紴層は垤殖を起して厚くふつてい る.筷粗結締織には一部に世血を認め, この大部分に

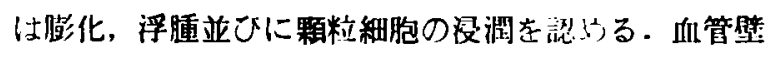
は一般に硝子化し，中に秃栓を認める。腺は萎䑿性で 尖战腹は膨化している。 


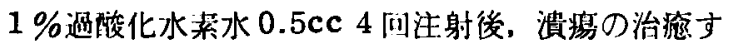
るまでの経過を観察するに４问注射後溃瘍は次第に

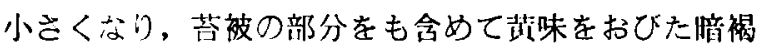
巴の疲皮よなつて，注射後 8〜14日こ脱落し般痕老残 して治捴した。

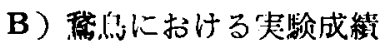

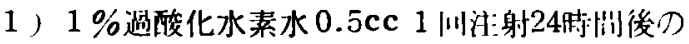
晹合.

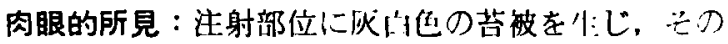

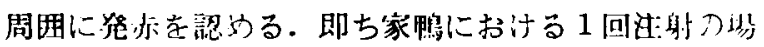
合の所見乞大压ない。

影貒鏡所見：上皮内に多数の大きな水疮を作门，水 疮内には多形核紐胞の多数游牥認力る。その一部は

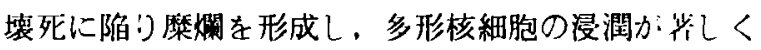
起つている.上皮下には浮朠が認められ，多形核科胞 が洒漫性に浸潤し少数の単核緗胞も認められる.しか し深部の結締織には一般に资㱏が弱

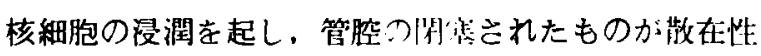
沪認められる。また所々に出血が見られる。

2) 24時閌問隔 2 回注射24時問後の場合.

肉眼的所見：1回注射の期合より灭白色の荅被が大 きくなり発赤ちやや強し．

影微鏡所見・上皮下には組織梂，多形核稩胞の洒漫 性浸潤と程維細胞の增殖が著明に認められる．深部の

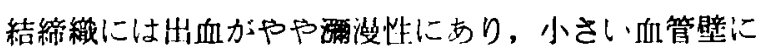
泣多形核科胞の浸潤を認引る。

C) 家來に扔ける実験成維

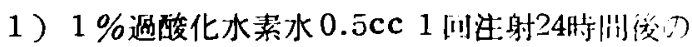
場合.

肉眼的所見・注射部位は狶废の発赤を呈するのみ

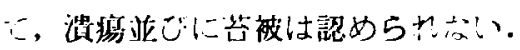

\section{顕微鏡所見 :}

a) 注射中心部

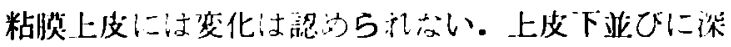

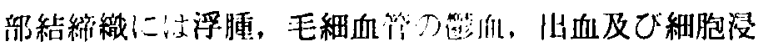

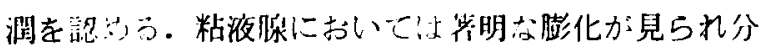

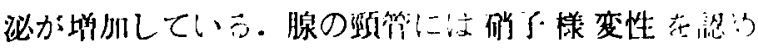
ろ.

b 注射周辺部

注射小心部の所見と大桨ない。

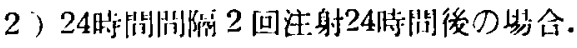

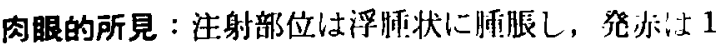

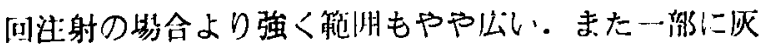
白色の薄い苔被を認める。 a) 注射中心部

粘䏚上皮には変化は認められ芯い，問質は浮腫か強

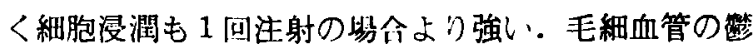
Ifll亚ひに㤕血も認められる。而管壁は一部に硝子様変 性を認めるが，大部分のもつには火し変化は諰めら れ亦い，粘液腺は腔が抎がり，腺練胞の空胞变性が強 人、此管の破壊も強い。

b ）注射周辽部

粘膜上皮の一部が变性を起し㔀脱している。兰の他 の変化は注射小心部之ほほ问様で，幾分程度が柽い。

3) 24 时間間隔 3 回㳀射 24 時開後の場合.

肉眼的所見：発赤は 2 问注射の妙命より更に强く, ひどい所ては内仙血の像を是する．また薄い灰白色の 苔被が大きく䓋り，その一部にはやや厚い白色の苔被

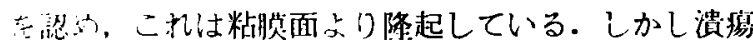
は認めら机视い。

\section{顥徽鏡所見}

a) 汗射中心紟

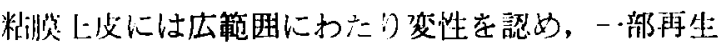
を見る．粘液腺の破填が強く認められ殆で腺の形態を 保つていない、て細血管の造血，出血並ひに細胞浸潤 を羿りる・大きい血管壁には大した变化は認められな

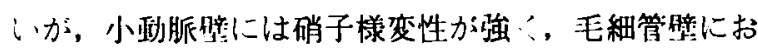
いても烇度の硝子様变性を珰动る。

b ) 浩射周辺部

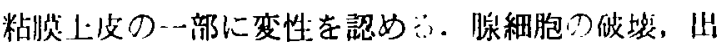
近，細胞浸潤等を認めるが注射小心部より整度てあ 3.

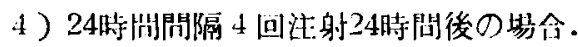

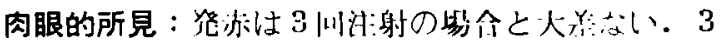

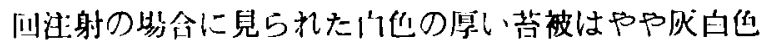

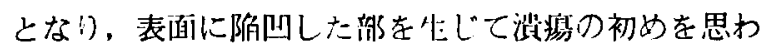
せた。

\section{顕微鏡所見 :}

a) 注射中心部

粘顺し支には一部変性ををきたし，また再尘の像が見

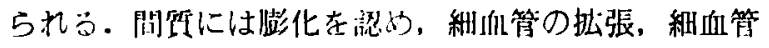

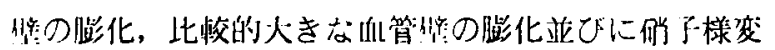

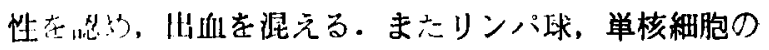

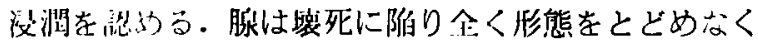

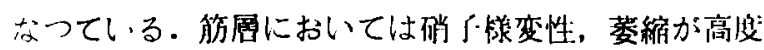
に見られる，以上の変化は限局ざれる伊向にあり，㣠 変のひどい部は非常にひどく、隣接淿は程度が怪い。 また外よ゙障碍されない缡も見られる。

b ) 洲:射周辺部 


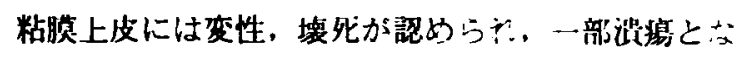

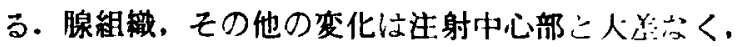
しかも病变が比較的限局さ机ている。また破装された 腺の間には線䊒芽細胞の增殖が強、起つている。

次に $1 \%$ 過酸化水菜水 $0.5 \mathrm{cc}$ の生射を更に24時䦓問 障で続けてみた処，5回过射24時間後に肉眼的にも交

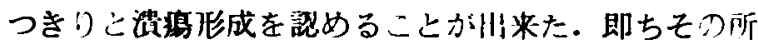

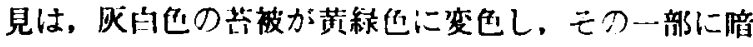

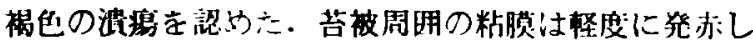
ていた.

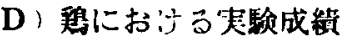

肉眼的所見：注射部位は内比血せる细くやや青出を おひる.注射周辺部は内什血の像か强く、またや管

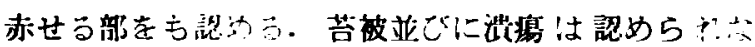
い.

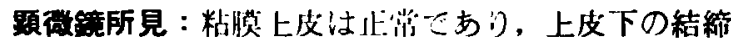

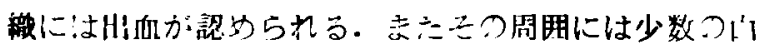

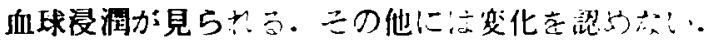

\section{第4章 考按並ひに稳括}

抑々カタラーセ䤃素については数多くの研究がなさ れているが, Theńard (1811), Schönbein (1863), Loew (1901) 等の研究以来, カタラーゼ醅素の主な 機能は過酸化水素を水と酸素上沪分解するにあるこ考 污られて六。即ち生体酸化によ!産生される過酸化 办素を分解し，その毒性よ门牛体を保讙している亡考 えられてきた。しかし最近 Keilin 並びに Hartree の研究によりカタラーゼ睹菜は更に公い生理的機能を 有し，或る条作のもとては peroxidatic に作用する ここが述へうれている，かかるカタラーセ醭素は第二

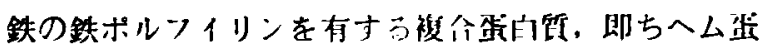

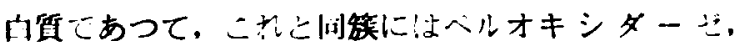
組織呼吸に可要なへモクロビン，ミオクロビンチト クローム等か存する. 次にカタラーセ䣼素の体內分优

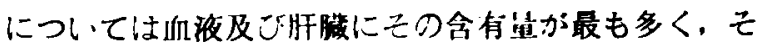

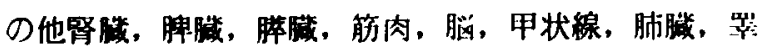
丸等にも多く含有されているといわれている。いずれ にしても生体を稚持する為にはカタラーゼ醉素が何可 欠のものてあると考汒られてきたたけに，本柱の発見

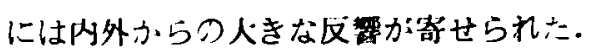

㧋て本症において出現する特異な口腹壊犹の所見に ついては，楮言において概略的にこれを述へたが，昭

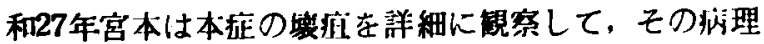
組穖学的所見を次のように述へている。即ち肉眼的所

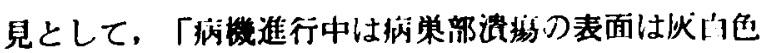

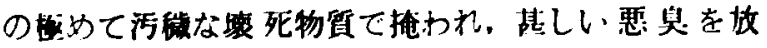

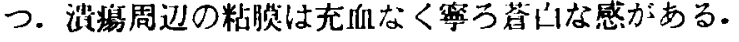

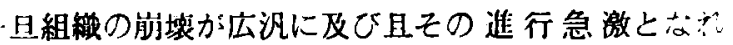

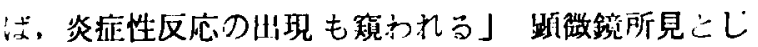

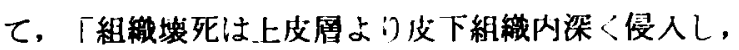
末だ塤死に陮らない組織との分界線は叮成明暸であ る.分界線附近におい、ては中等㡲の门血球の游州があ り，所々多数群果している简所が見られる。しかし深

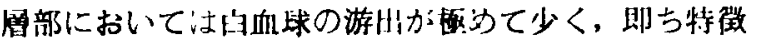
として組維溒死の旺盛なのに比して緗胞唚潤は少い感 がある」こ述へている．また血管傿の弾力及し膠原線

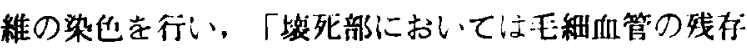
するものは勿諭なく，また分界線附近を走行毛科 管のなかには，弾力線維の走行の乱於もの，或は断 裂壊死に陥つたもの等が訆めら机た」こも述いてい る.

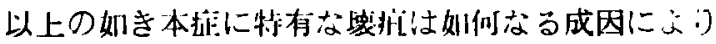

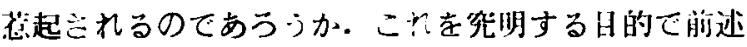

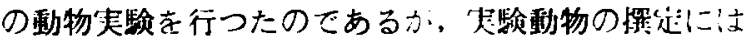

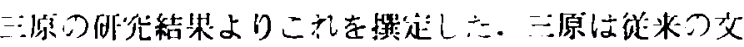
献を参照して，その血唯中沪力タラーゼ含舅が少いと

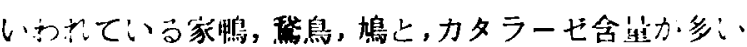

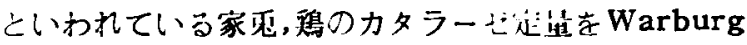
氏娭比装置を使用して藤田，兄玉 氏法により行い，

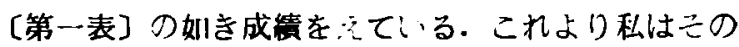
沿液力タラーセ含量が本主患者に最も近く，しかもそ の血液に過酸化水素水を注加した场合に直に照変し。

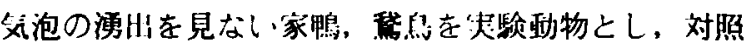
としては普通量に向液カタラーゼ含量する家鬼（血

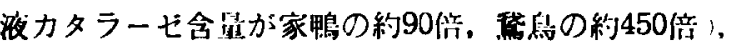

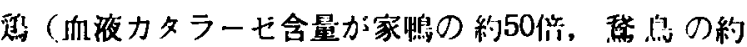

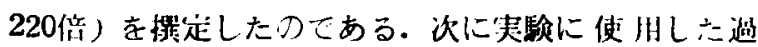

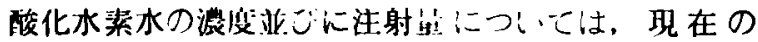

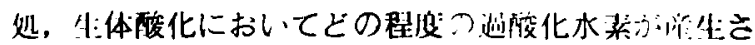

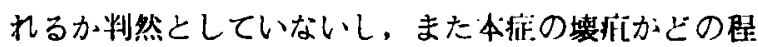

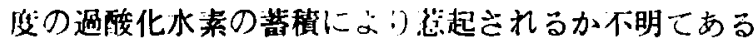
ので，この決定には四感した。藤时，兄玉は脯炎球获

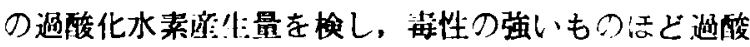

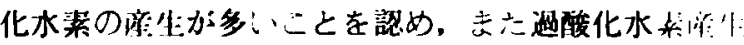

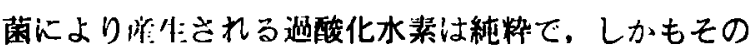
酸化㹝が強いら述へているので，先ず武みに3\%過酸 化水素水（オキシドール）をWarburg 氏検生装置を

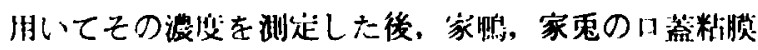
下に1ccずつ清射してみた。これにより家鴨において

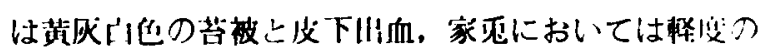

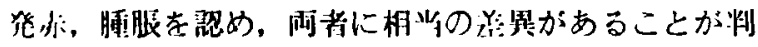




$$
\text { 第一表 }
$$

\begin{tabular}{|c|c|c|c|c|c|}
\hline & 家鴨 & 悲鳥 & 沜 & 默 & 家鬼 \\
\hline 血 液 & 37 & 7 & 10 & 1536 & 2970 \\
\hline 口腔粘膜 & 14 & $3 ?$ & 0 & 17 & 75 \\
\hline
\end{tabular}

明したので，実䮖には3\%過酸化水菜水を $1 \%$ に稀釈 し、その0.5ccを注射したのである。

実駼成綪を要約すると, 肉眼的所見では家鴨及び程 鳥に市いては 1 回注射 24 時間後に灰白色の荅被 じ, 家鴨においては24時間間隔 3 回过射後24時間で污

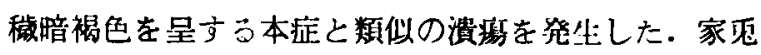
及ひ鴊に招いては，1，2 回注射24時間後ては柽度の発 亦を諰めるのみで殆ど变化を認め立，家象においては

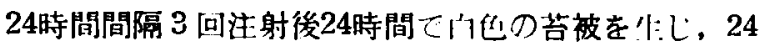

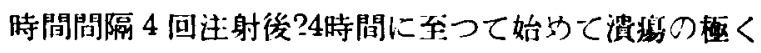
初斺を思わせる状悲となり，更に24時間間隔 5 问注射

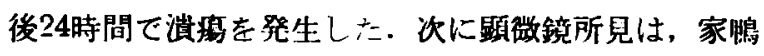
においては著明な血管壁と筋肉の変化を認めた。即ち 筋䅉においては 1 回注射24時間後にすてに筋紐胞の笠 胞或は硝子様変性を認め, 更に注射回数を增すと著明 な筋線維つ硝子様变性, 顆粒細胞の浸澗, 出血, 筀線 䊒の萎縮を認め, 更に進むと烄死に陌り、所によつて

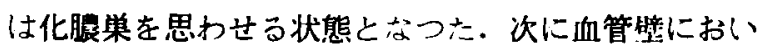
ては 1 回注射24時間後に太い血管の外膜に确子様变性

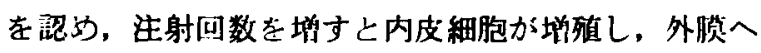

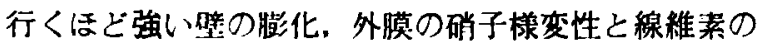
生成が訆めら兄、また外脱より内膛に至るまで顆粒細 胞の浸潤を認めた。管䶼には㢣血，更に進むと血栓形 成を起し，腔の閉空をきたしているものがあつた．最 後に壁法外脱より次第に髙死に陷つていく．以上の变 化は動脈において强く認められ，これ流血管外からの 原因により惹起されたものと考えられる。線紐胞にお いては初方分祕公谁つ像を呈し、後次第に萎維性よな

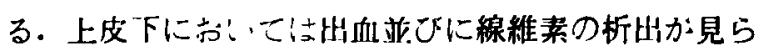
れ，汇射回数老的广につれて，上皮全層に分剽された

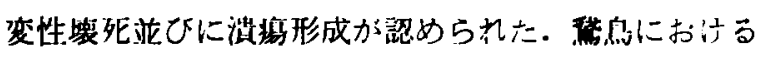
変化は家鴨のこ只と殆ど頑似していな。家琶における

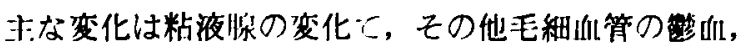

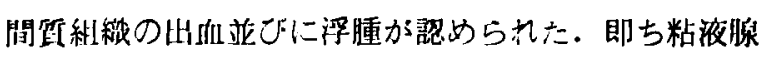
においては 1 回注射24㭙間後には硝子㥞变性或は膨化 をきたして分泌元進の像が見られ，更に進むと腺の破

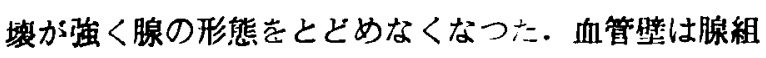

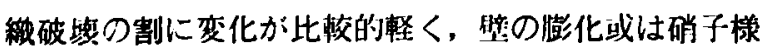
变性が認められる程度であつた。筋肉においては周岄

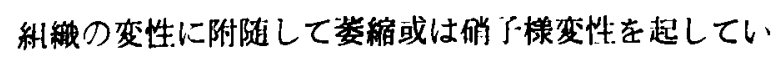

た、きた上皮は注射回数を增すにつれて次第に変性壇

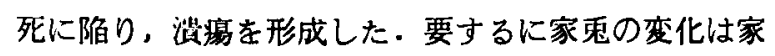
鸭の変化に比べ程偍が㩽く，しかも浅在性で限局され

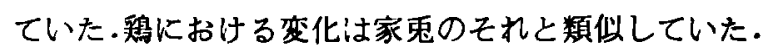

以上が実粉成績の要約であるが，家鴨における成績 が肉眼的にも湿微鏡的にも本症のそれと類似していた 点は特に興味深く, 本症に出現する口腔壊㾞が細菌に より産生された過酸化水素の蓄積により莣起されると いう高原等の考湾を肯定するものである.また家鬼に おける变化が家瑝のそれに比へて軽く，しかも浅在性 で限局されていたという点は，血液並びに組織カタラ 一セ含量の差により,カタラーゼ䣼素の保護をより多 く受けたということに他ならない、しかし血液カタラ 一七゙含量が普通皆てある家鬼においても, 過酸化水素 水を反復注射した際に溃韵形成を見たことは，過酸化 水菜の強力な酸化作用之, これに対するカタラーゼ䣼 菜この他による組織休濩作用の限界を考える时, 当然 といわねばならないでうう。しからば帮カタラーゼ 血液症患者の組䄉に過悛化水菜が作用した埸会に, 如 似㐫る機枟により, 或は如何なる過程を経て烄疜が発

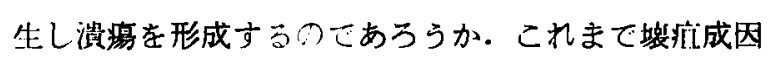
焱明に関する研究は芯々な角度より試みられている。 即方宫本は病变の進行は緩徐であるが, この組織崩哕 力の箸しく広汎且旺盛てある点より, 先大性免疫力の 低下があるのではないかと考泣，患者について補体何 测走, オプソニン検查, 白监球つ喰菌指数测定等を行 つたが、いずれも正常であつたと述へている。また向 井は渦酸化水素によるカタラーゼ欠損組織の壊死性障 碍の原因について実鈋的考察を試みる為, 組䋨細胞に あつて過酸化水素と反応する可能性の大きい, 思われ る物質について，過酸化水素との反応性を检討してい，

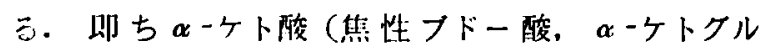

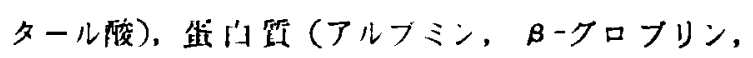

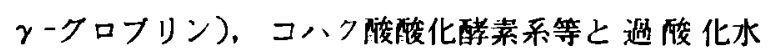
卖乞の反応老娭し、コハク酸酸化酵素系において最も

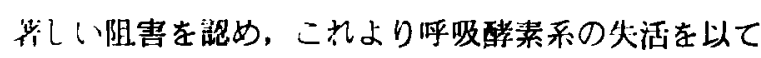
私北成因であるこしている。また今川及び中村は口沿

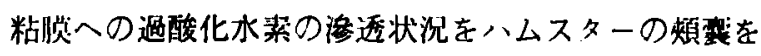

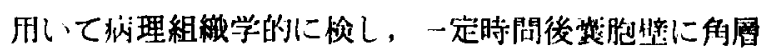
の憉化，筋組織の变性，上文下組織の充血，出血，浮 腄並び細胞浸润老認めている。また水原, 沖田, 大 不等は本症患者の酸化醭热の活性度について実䮖を行 い三の異常ないことを確めている．しかしこれ等贵重

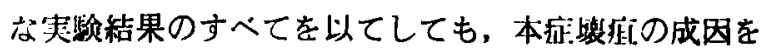
結拥つけることは出来ない。またこれ等は主に in vitroの実频であつて，坫㑤成因の解明には一少進ん 
で本症患者と最も近い状態にある動物においての実騟 が必要であると考にるのである.かくして私は先人と は異なる䚀点より，実駼動物に過酸化水素水を逨続注

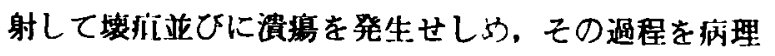

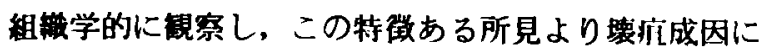
ついての推察を試みんとしたのである.

実驗結果より最も有意義と思われたことは，本庭患 者亡最も近い血液力タラーゼ优を有する家畹におい て、その罗病形成の過程中，血管壁（特に動脈壁）並 ひに筋肉に特に強い变化が認められたということであ る. 従つてこれを中心として考察を加えていくことと

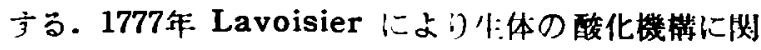
する研究がなされて以米、この方面についての数多く の研究が見られるが、これを組樴呼吸の面から述べれ

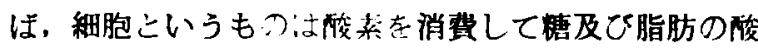
化を行い，䅂局的に $\mathrm{CO}_{2}$ 亡水とにし，この際に遊離 されるエネルギーを利用して物理的乃主化学的化事を 遂行しているということが㤕来る。この過昆には緗胞 内の多数の醉素群及じ酸化退元系が則与し，これが円 骽進行しているらうてある。このうち特に組維や細 胞の呼㖟に関して決定的な意義を有しているもの注含 鉄色素蛋白群であつて、これにはへモクロビン、ミオ クロビン, チトクローム等が包含される。その他広㼁

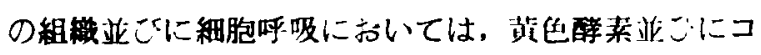

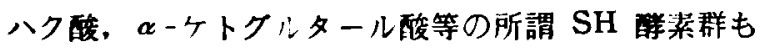
関与している。含䤠醉素群は上代が本症の病因につい て述ヘている如く，過酸化水素に対して竌和性が强 く，その鉄原子により過酸化水素と結合し，結柴とし てそれを処理分解する能力を有しているか，生理的港 度を越无る過酸化水䒺の蓄程が起つた際には，カタラ

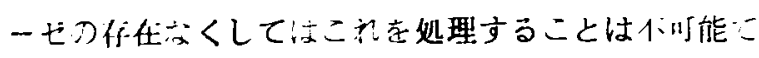

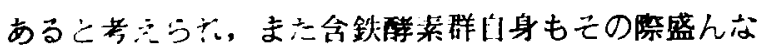

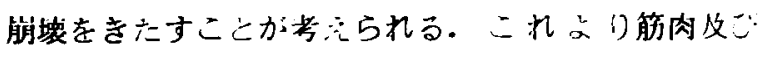
血管壁 (哖に動脈等) の变化が特に著明であつたこと は, 稩血管壁も主に滑平筋線維から出来ており, 筋肉 中に多虬会まれるミオクロビン。チトクローム等, 含鉄色素蛋白群の障害により租織亚ひに綀胞の酸化過 程が遮断され，退行変性をきたしたものと思われる. ミオクロビンはへモクロビンに比べの酸菜に対する 親和力が大で、亦血球㠶オシ・へモクロビンふう 酸素を筋組織に導き入れ，乳酸の酸化に供する役目を 有し、チトクロームはFruton \& Simmondsが Keilin 以米の種々なる実悇結果より述へている如く，好父性． 生物及じ組舸の呼吸は大部分このチトクローム等を程 て行われ，州に非酸化において重要な位置を占めて
いることが喼められている，従つてこれ等の障害が組 織の退行変性を発来することは当然考况られる処であ り，乙の際闰時に萑起され心血管壁（特に動脈暨）の

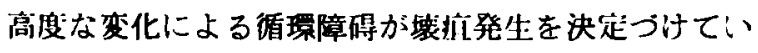
るものと思惟されるのである．また间時に見られた紐 胞曼潤等の炎症性变化は，退行性变化に附随したもの と考沉られる。以上の考察は, 宮本が述へている本症

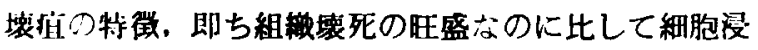
潤が少いということを或る程度説明出来るのこはなか ろうか.

最後に以上の如き実験的に発生せしめた壇妆の成因

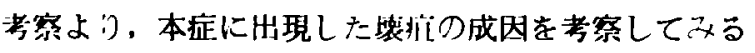
と,

1 ) 血液力タラーセの画力て少い家鸭において, 過

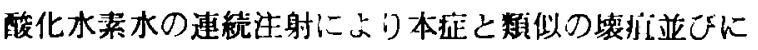

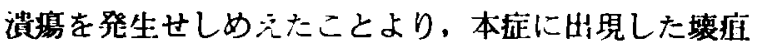

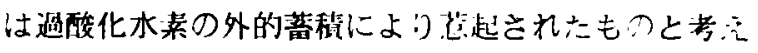
られる。

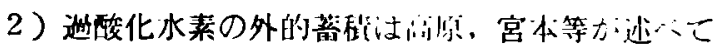

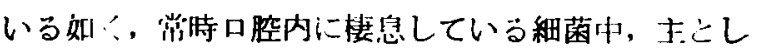
て過酸化水集産生菌であつて且カタラーゼを彦生し ない溶連菌, 肺炎菌、乳酸菌等の多数感染によるもの 之考云られる。

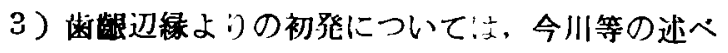
ている過酸化水素の川腔粘荧への透過性も関倸ありと 思林が、これに加うるに泝项部の細菌繁殖に有利

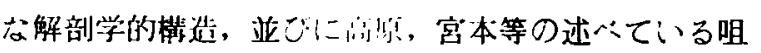

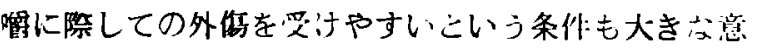

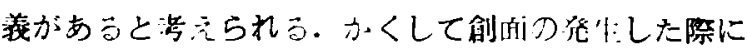
は，過酸化水素の組峨に対する影勄も更に強まり，上 述の条俳も加つて組䄉の退行変性へ上進むつて法か。 ううか.

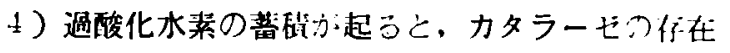
し交い本症患者の組樴においては決定的な障碍が見へ。 る。即ち組織紐胞中のチトフローム、ミオフロビン,

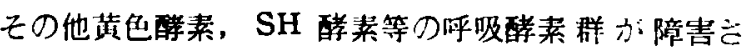
れ，この結果，組織細胞の酸化逊元系が遮断されて退 行变性を菼起する.この際间時に血管壁(特に動脈照)

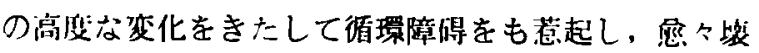

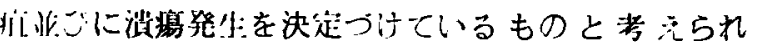
る. しかして上代, 吉屋, 何井等の述へている呼吸醋

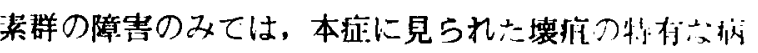

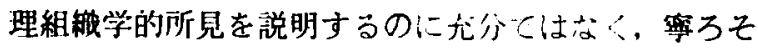

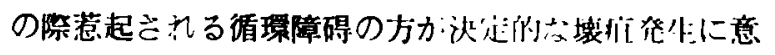
義を有するものと思われ

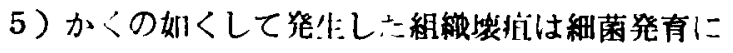


好適条件を与之，両ヶ相俟つて進行性に抬人するもの であろう・

6 ）高原, 宮本等が述べているオキシ・ヘモグロビ ンの酸化による酸素運搬能力の障碍が本症填瘨の成因 であろらといらことについては, 過酸化水素の蓄積を きたした際に末梢血液中にかかる現象が認められると は思われるが，これが本症填瘨の主因であるというこ 亡は私の実験から推測することが出来なかつた。

以上が私の実騟結果より見た本症壊疗の成因に閵す る考察であるが，この間題は容易に解決されうるもの ではなく，今後更に組織化学的方面よりの追究を行法 ば，一段と解決に近づくものと思加れる。

\section{第5章結語}

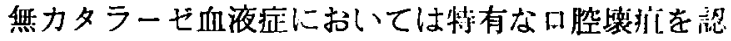
めることが多い：この溒店の成因を究明する為に動物 実験を行つた．即ち血液力タラーゼ含量の極めて少い 家鴨及び黛鳥室駼動物として選ひ，対照として家鬼 及び峝を用いて，それぞれの口蓋粘膜下に $1 \%$ 過酸化 水素水老注射し，一定時間後これを病理組織学的に検 索した・実験結果は

1) 家鸭においては肉眼的に24時問間隔 3 回过射後

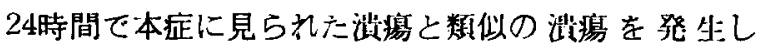
た.顕微鏡的には著明な血管壁と筋肉の变化を認めた。

\section{主 要}

1) J. S. Fruton \& S. Simmonds : General Biochemistry, 154.

2 ) D. Keilin \& E. F. Hartree : Bioch. 'J., 39, 293, 1945.

3) D. Keilin \& E. F. Hartree : Bioch. J., 60 , 310, 1955.

4) S. Takahara : Proceed. of the Japan Academy, 27, 295, 1951.

5 ) S. Takahara: Proceed. of the Japan Academy, 28, 28:, 195 ?.

6) S. Takahara : The Lancet, Dec., 6, 1101, 1952.

7 ) S. Takahara : The Laryngoscope, 64, 685, 1954.

8）高原，笘术：耳喉科，21奖，53.

9 ) 宮本 : 岡山医学会雑誌, 64炎, 827, 837.

10）上代 : 綜合医学, 12 炎, 915.

11）皆屋：口腔病学会傕洁, 19 登, 18.
2）瑟鳥における变化は家鴨のそれと殆ど類似して いた.

3）家鬼における変化は家呞に比へて軽度であり， しかも浅在性で注射部位に限局していた。

4) 舀における变化は家鬼のそれと類似していた。

以上の実駼結果より，家鴨並ひに瑟鳥において能肉 及び血管壁の变化が家鬼並びに彩に比べ著明であつた ことは，筋肉中に含まれるミオグロビン，チトクロー 么等の過酸化水素に強い親和性を有する含鉄色素蛋白 が，カタラーセが少い為に家雨, 貌の場合よりも, より強く過酸化水素の酸化作用学受けて, 退行性病变 をきたす為であろうと思惟された。これよりして本症

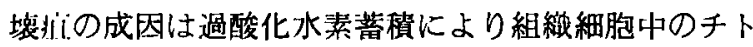
クローム, ミオクロビン, その他黄色酵素, SH 酵素 等の所謂呼吸酵素群が障害されて組織の退行変性をき たし，间時に惹起された血管壁（特に動脈壁）の高度 な変化による循環障䄍が填疸発生を決定つけているも のと考えられた。

擱筆するに当り御郎切なる御指導と御校閲をいただ いた恩所高原滋夫教授に深甚の謝意在表するととも に，御指導いただいた疮理学教室妹尾左知丸教授に㳭 謝いたします。

なお本論文の要旨は日本耳鵕咽侯科学会第77问中国 地方会において発表した。

\section{文献}

12) 三原：岡䛈学会雑誌, 68卷, 2167.

13）高原：岡山医学会雑誌, 63年, 8 .

14) 向井:日本口腔科学会雑誌, 5 巻, 369 .

15）沖田，大不：岡山矤学会雑誌，67卷，905.

16) 沖田：生化学, 27 巻, 746.

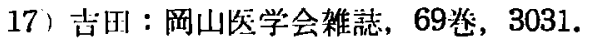

18) 吉川: 綜合矤学, 12炎, 809.

19) 戸时：新細闻学, 307.

20)网: 組峨学, 124 .

21) 赫松: 生化学, 128.

22) 神新 : 酵素学, 417 .

23）緒方, 三田村：病理学総淪, 中㥕, 306.

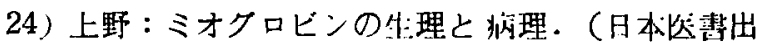
版)

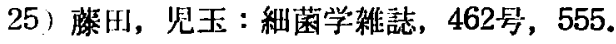

26）上代, 中尾，他：愐色素の生理と陑床.

27）昭和32年度文部省総合矿究辫告集録（医学及ひ薬 学縟)，然力タラーゼ们液症の研究，105. 


\section{附図説明}

1） $1 \%$ 過酸化水素水 1 回注射24时間後（家鴨肉眼的所見）：注射部位に灰台色の苔被を生じ，その周曲はやや発 赤す。

2）24時間間隔 2 回注射24時間後（同上）：苦被は大きくなり，発赤の程度もやや強度しなる。

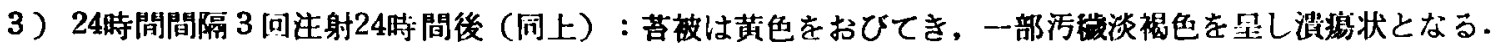

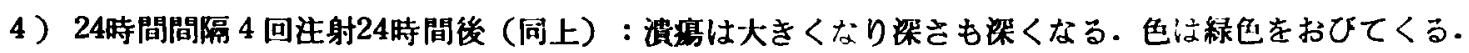

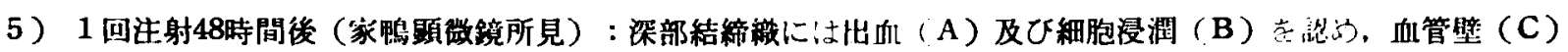
には膨化，硝子様変性を認める。

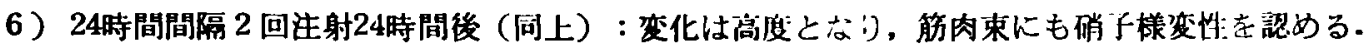

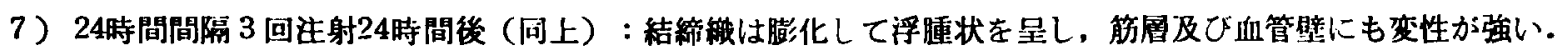

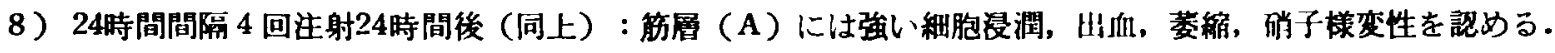

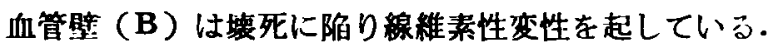

9） 1 回注射24時間後（家象肉眼的所見）：注射部位に軽信の発赤を鼣める.

10） 24 時問間隔 2 回注射24時間後（问上）：浮腫状腫脹並びに発亦を認める.

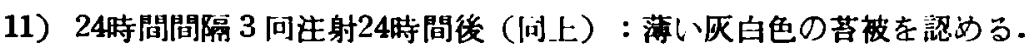

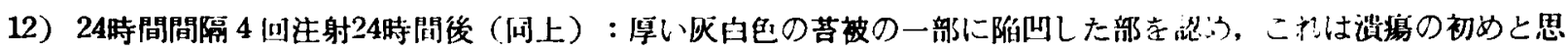
Dr.a.

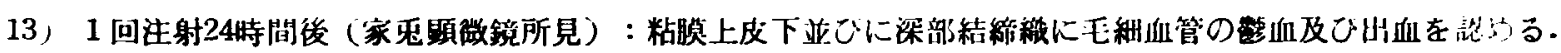

14）24時間間隔 3 [叮注射24特間後（间上）：粘夜腺の破填か強く認められ（A)，殆と腺の形態を保つていない。

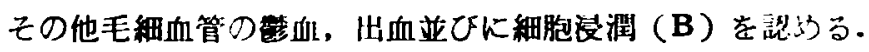

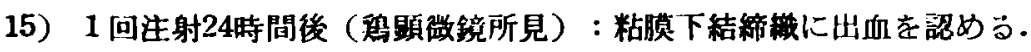

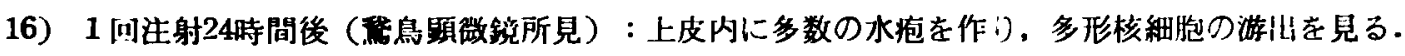

17） 1 回注射24侍閣後（同上）：血管壁に多形核細胞の曼洞を起している.所々に仙血も見られる。 


\title{
Experimental Study on the Oral Gangrene appearing in Acatalasemia
}

\author{
Katsusaburo DOI \\ Department of Oto-Rhino-Laryngology \\ Okayama University Medical School \\ (Director. Prof. Shigeo Takahara)
}

In acatalasemia we often encounter a specific oral gangrene. With the purpose to elucidate the causative factor of this gangrene the author performed animal experiments. Namely, ducks and geese having only a trace of catalase in their blood were selected as experimental animals and for the control group rabbits and hens were used. By injecting $1 \%$ hydrogen peroxide solution under the mucous membrane of the palate in respective animals histopathological investigations were carried out at a fixed time after the injection, and the following results were obtained.

1. Macroscopically in the ducks 24 hours after three injections of $1 \%$ hydrogen peroxide solution at intervals of 24 hours there appeared gangrene resembling the one observable in acatalasemia cases, and microscopically marked changes were recognized in blood vessel wall and muscles.

2. The pathological findings induced by experiments in geese were marked and almost identical with those in ducks.

3. The induced changes in rabbits were superficial and milder than those in ducks, being circumscribed at the site in injection.

4. The changes in hens resembled those in rabbits.

From these results it is assumed that the fact that the changes in the muscles and blood vessel wall in the ducks and geese with almost no catalase were more marked than those in the rabbits and hens proves that the iron-carrying chromoproteins possessing a strong affinity to hydrogen peroxides such as myoglobin and cytochromes contained in muscles, are affected more strongly by the oxidative action of hydrogen peroxide than in the case of rabbits and hens, thus bringing about the retrogressive degeneration. Therefore, it seems that the causative factor of the gangrene in acatalasemia cases lies in the fact that the so-called respiratory enzyme group such as cytochromes, myoglobin as well as yellow enzymes and SH enzymes contained in tissue cells are disturbed by the accumulation of hydrogen peroxide with resultant retrogressive degeneration of tissues, as well as that the circulatory disturbances brought about by the marked changes in blood vessel wall (especially the wall of arteries, seem to evoke definitively the occurrence of gangrene. 


\section{土井論文附圆}
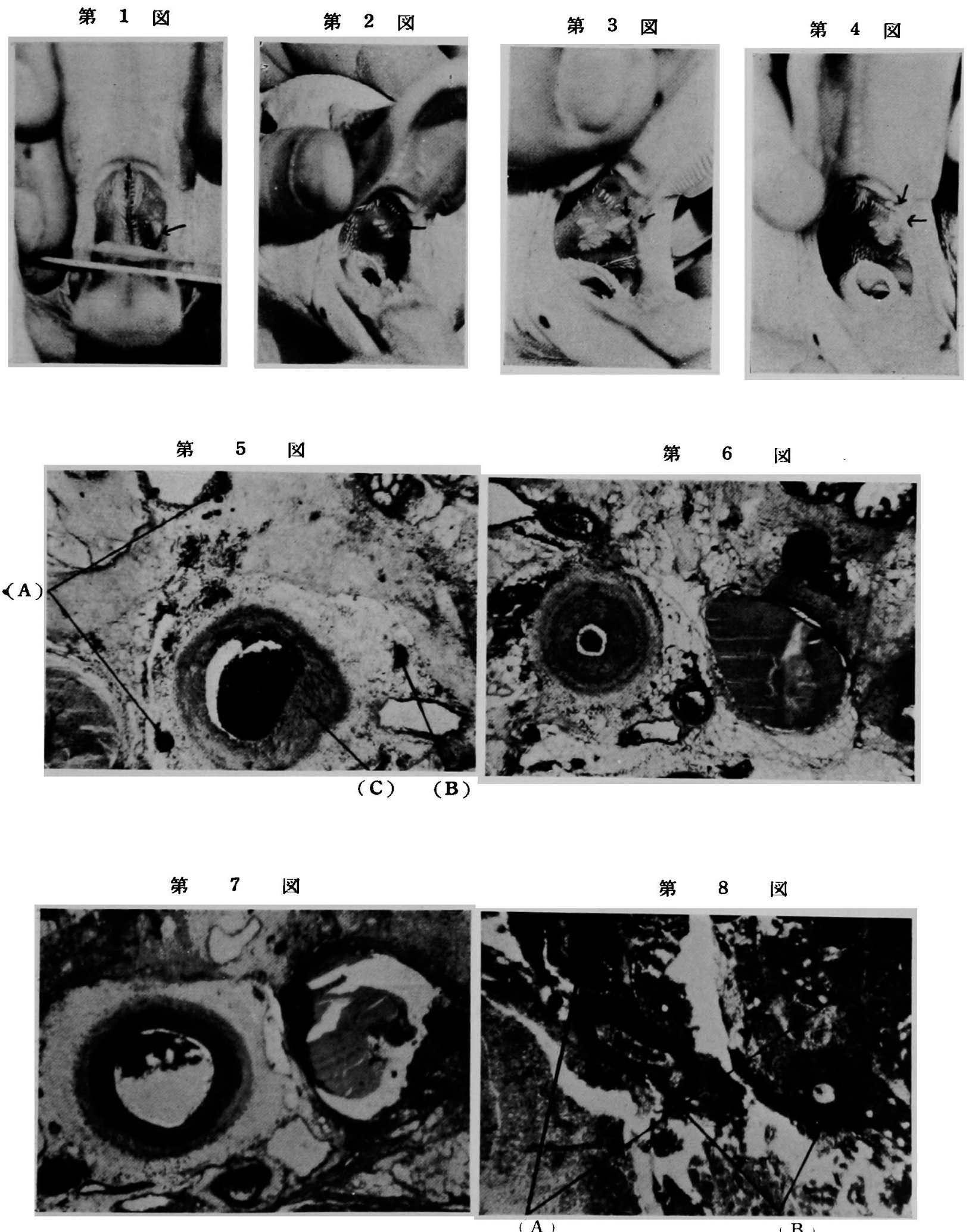


$$
\begin{aligned}
& \text { 土井勝三郎 } \\
& \text { 土开論 女 附図 }
\end{aligned}
$$

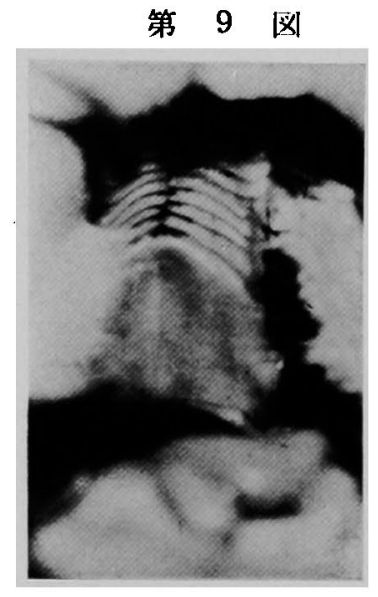

第 10 図

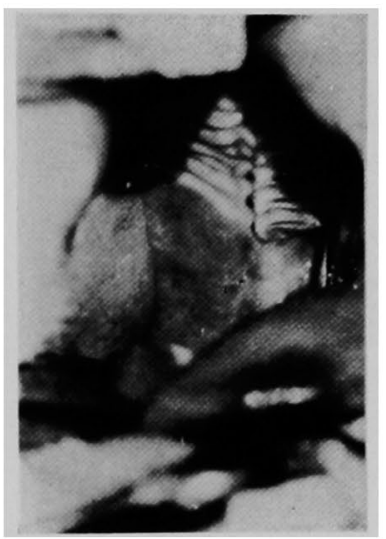

第 11 図

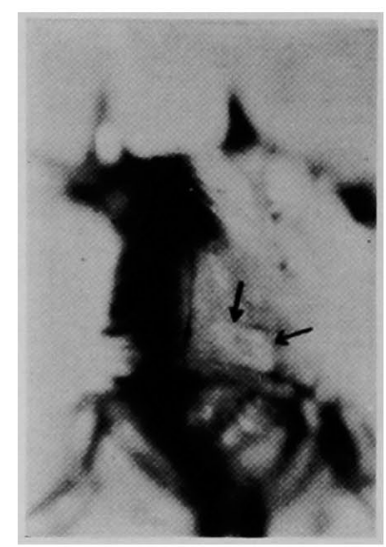

第 12 図

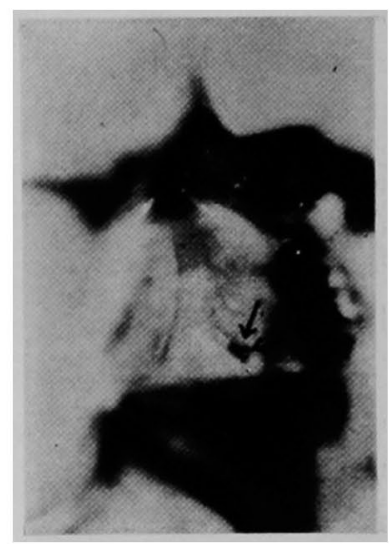

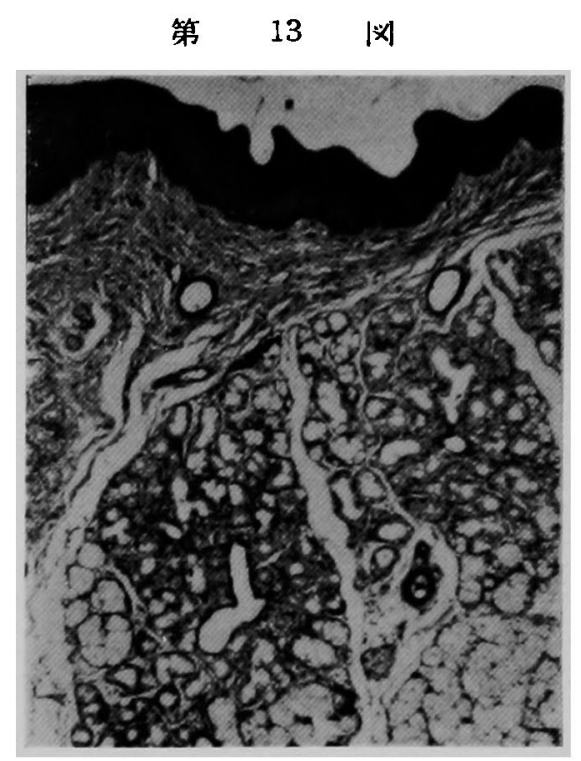

第14

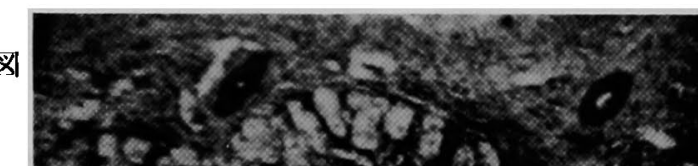

(A)

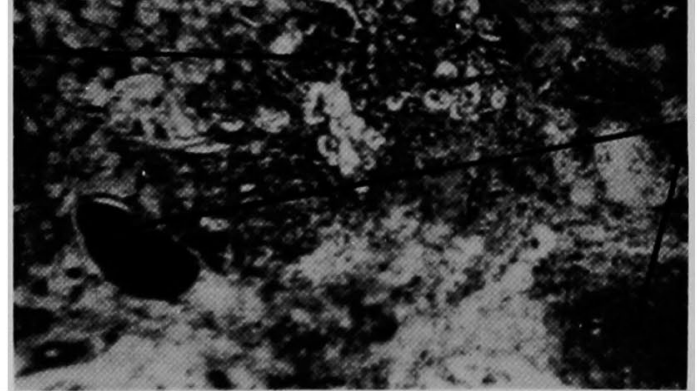

B )

第16図

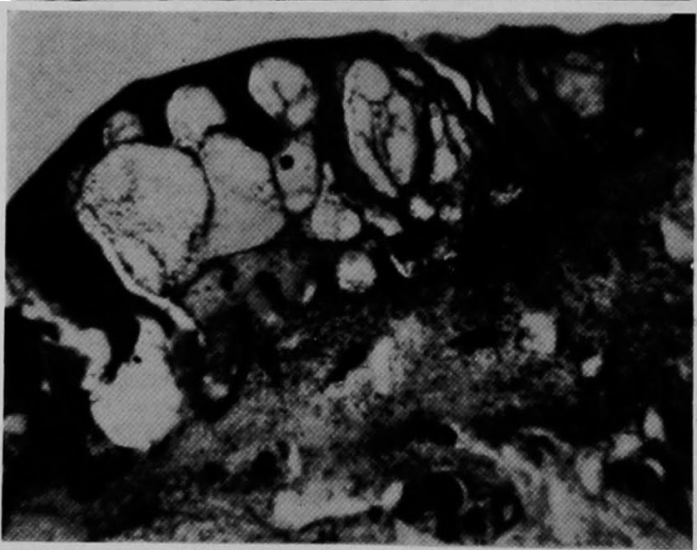

第17|这|

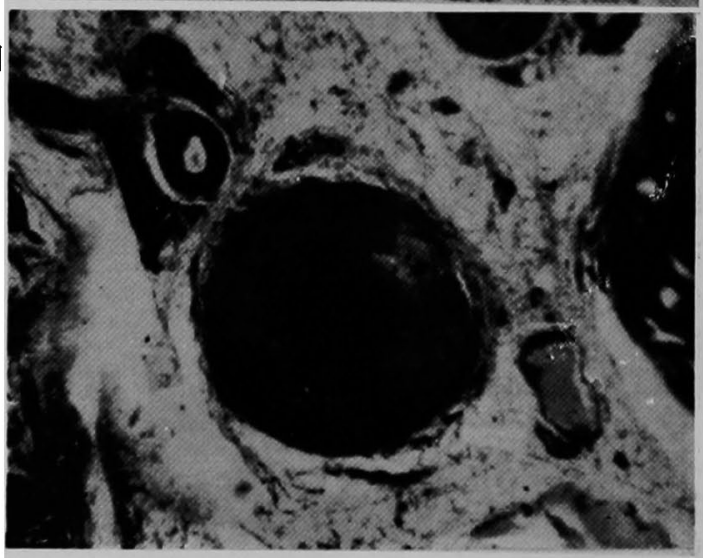

